\title{
Organizational Service Orientation as a Quality Predicator in Services
}

\author{
Wieslaw Urban \\ Bialystok University of Technology, Faculty of Management \\ Poland
}

\section{Introduction}

The concept of the "service economy" was reviled many years ago, but some crucial issues like service quality are still interesting as research fields. Now, in the globalized, web 2.0 economy, services are an area of many outstanding challenges to managers. The old question very often asked by managers, "How can I delight my customers?" sounds every time fresh and curiously. Even in the digitalised world, when customer service staff use intensively electronic devices while serving customers, quality is still crucial and challengeable, because on the two sides of a Skype connection or an e-mail exchange they are real humans. Staff can provide outstanding service via the latest Facebook communication interface and delight their customers, or staff can provide poor service via the same channel disregarding customers, and treating them as petitioners. Customer services are taking on an ever-increasing level of importance in today's global economy (Baydoun et al., 2001). Furthermore, we can observe the growing popularity of the service approach to management. According to Vargo \& Lusch (2004), service logic is valid not only in what have traditionally been called services, but also in all industries in the economy.

A service product must be provided well first time, and there is no room for failure because service production takes place at the interactive with customers. The quality of interaction in the service encounter, and customer service experiences, lead to customer loyalty, and are very often treated as the key factors of a successful business. A service organization must be fully prepared to provide excellent service. On the other hand, managers need to know the capability of an organization to provide superior services. In this context there is the very important task of searching for organizational predicators of excellent outcomes provided to customers, as well as assessment methods of an organization's ability to provide excellent services. That is why the organizational service orientation concept is proposed for deep examination in this chapter.

In the stream of different concepts which are trying to assess an organization's ability to provide excellent service outcome the idea of organizational service orientation seems to be particularly useful, but it is not a widely practiced approach among managers and researchers. Organizational service orientation is very closely related to the corporate culture concept, and describes a staff approach which is directly connected to quality of service delivery; it determines the state of all interactions between an organization and its customers. 
This chapter elaborates on the problem of organizational service orientation and a few related concepts. There is an attempt to evaluate the state of organizational service orientation in the service industry in Poland. The cross-sector approach is employed, and the problem of the differences of organizational service orientation in different service sectors is examined. A wide cross-sector study has not appeared before in an investigation of organizational service orientation. The chapter provides an exhaustive analysis of some theoretical concepts related to organizational service orientation, which may be valuable for a better understanding of the assumed research approach.

\section{The link between inside and outside service quality}

The classic approach to quality management, namely TQM, is mostly focused on quality in the internal meaning. The excellence of activities done by people from inside a company this is the main aim in this approach. Nevertheless, in service research it is noticeable that most studies have considered only quality experienced by customers (Mukherjee \& Malhotra, 2006). Very often the discussions about quality in services exclusively take into consideration the customers' perception context. The meaning of quality as customers' experiences is different from the organizational one because this is an individual and subjective concept. So, in the literature output we have a few models trying to link inside service quality with the quality experienced by customers, i.e. outside service quality. Researchers are also looking for the organizational predicators of quality experienced by customers, as well as the relationships between the state of the organizational service system and the effects on business.

The widest known concept which links the internal and external sides in services is given by Heskett et al. (2008). This is the Service-Profit Chain concept, where company profit and precedent customer satisfaction are affected by the service delivery system, and all have their sources in internal service quality. The concept underlines the fundamental meaning of the inside quality of activities in an organization while building customer satisfaction and, finally, profitability. Another theory explains customer perceived quality by gaps which appear in a service organization. This is the five quality gaps model proposed by Parasuraman et al. (1988). According to the authors the quality experienced by customers depends upon the information loop passing through an organization, which informs us about the customers' real expectations. Four gaps influence the customers' perception of quality. The first one exists in managers' perceptions about what customers desire from services. The second one is contained in the specifications prepared by managers. The third one is how the specifications are delivered to customers, and the final one appears in external communications giving information on the service quality that a company offers to deliver.

There are many more pieces of research which look for predicators of customer service quality and customer satisfaction in many different spheres of an organization. According to some authors, customer-contact employees' job standardisation might lead to a higher level of service quality experienced by customers (Hsieh \& Hsieh, 2001). Others underline the role of staff empowerment in achieving high service quality (Ueno, 2008). Management techniques (Kantsperger \& Kunz, 2005) and employees' effort, involvement and abilities (Specht et al., 2007) are also treated as factors predicating customers' perceived quality. Johnston \& Clark (2005) underline the importance of the service 
processes in creating the customers' service experience. Also Urban (2011) proposes the service quality measurement model which simultaneously evaluates organizational service processes and customers' perception.

Another bundle of factors leading to customers' superior experiences lies in the corporate culture of a service organization. Schneider et al. (1998), grasping what is specific in corporate culture to a service organization, exhibit how the service climate leads to customer perceptions of service quality. The issue of searching for predicators of customers' superior experiences in close-to-culture spheres of the service organization is the leitmotif of this chapter.

\section{Organizational culture in services}

Among the many factors affecting market and financial success of an organization, the culture code within an organization is considered an important predicator of market and financial performance. In the classic work "In Search of Excellence" by Peters \& Waterman (1982) the authors conclude that the most successful companies have expressive and clearly defined organizational cultures. The authors clearly indicate that any organization in order to survive and achieve success must have a specific set of beliefs and values. These beliefs and values influence the policies and actions of companies. These beliefs and values are very stable. Almost anything can be changed while adjusting an organization to forthcoming challenges, but they are constant in the long term.

Hofstede (1997) sees values as the centre of the culture. From values emerge practices which are symbols, heroes and rituals. Values are closely linked to a tendency for certain decisions to be made by people. According to this author the organizational culture differs mainly at the level of practices which are characteristic for particular organizations. Others, for example, propose that organizational culture refers to values in the context of expectations, support and rewards in an organization, as well as norms on which polices, practices and procedures in an organization are based, and finally the common, shared interpretations of values and norms within an organization (Schneider 1988). Values and norms are not directly observable in an organization, but we can see practices, procedures and behaviours driven by them. In the culture phenomenon visible and invisible elements coexist in mutual interdependence. Culture is also the essence of organizational identity. It provides the basic guidelines for employees, and that is why it is called the collective programming of the mind.

In the literature output we can find the specific interpretation of organizational culture in particular service industries. Beitelspacher et al. (2011) suggest that service culture in a retail organization should be meant as a customer-centric culture, which aims at exceeding customer expectations, and is strongly focused on providing superior customer value. If the culture is beneficial, it should be strongly associated with the knowledge and skills development of employees.

The positive influence of service culture on the key performance variables of an organization can be observed. Empirical research points out that first of all it leads to better customer perception of service quality, as well as having a beneficial impact on customer market loyalty, repurchase intentions and customer satisfaction (Beitelspacher et al., 2011). This research, conducted in the retail industry, underlines the importance of the issue of 
organizational culture in the service context. Culture programming appears to be a meaningful issue for the endurance and long term development of a service enterprise. The positive relationship between organizational culture in a service organization and its performance, namely output quality and customer satisfaction, has been demonstrated by several studies (Winsted, 1997; Furrer et al., 2000; Kanousi, 2005).

Researchers also underline some differences between the corporate culture in the general meaning and the service sense of corporate culture, so called service-oriented culture. Service-oriented culture has particular significance in manufacturing. According to Gebauer et al. (2010) it consists of service-oriented values and behaviours; the authors distinguish the values and behaviours of management and employees. Service-oriented aspects in the background of corporate culture refer to entrepreneurial orientation, real problem-solving eagerness, innovativeness, and employee flexibility. According to studies performed by authors, service-oriented elements in organizational culture are key factors in achieving sustainable business performance.

As we see from this short glance at organizational culture phenomenon, it includes significant factors which influence the organization's output, and it plays an important role in the long-term business success of an enterprise. It also offers a broad framework for particular conceptualization of this phenomenon for particular purposes. In this study the attention is focused most of all on the organizational service orientation concept.

\section{Organizational service orientation}

Among culture-originated concepts, which express an organization's ability to provide excellent service to customers, organizational service orientation concept seems to be very accurate and relevant. Organizational service orientation manifests itself in staff attitudes and behaviours which directly affect the quality of the service delivery process, and determine the state of all interactions between a service organization and its customers. An organizational service orientation is defined by Lytle et al. (1998, p. 459) as an organizationwide embracing of a basic set of relatively enduring organizational policies, practices and procedures intended to support and reward service-giving behaviours that create and deliver service excellence. At the visible level it is reflected by genuine attention to customer needs, as well as sharing, helping, assisting, and giving support to customers. Organizational service orientation is recognized as the kind of predisposition for giving superior service. Its supposed direct impact on the state of service provision makes this concept very interesting and potentially valuable.

The service orientation stays in a strong relationship with the intangible aspects of an organization. It exists when the organizational climate for service crafts, nurtures and rewards service practices and behaviours known to meet customer needs (Lynn et al., 2000, p. 282). It is also taken as something that manifests itself in the attitudes, as well as actions, of members of an organization which values highly the creation and delivery of excellent service (Yoon et al., 2007, p. 374).

According to Lytle et al. (1998) an organizational service orientation consists of fundamental elements which cover four delivery fields crucial for service, which are: (1) service leadership practices, (2) service encounter practices, (3) service system practices, and (4) human resource management practices. The proposed fields are fulfilled by specified 
elements which constitute the best-in-class service practices and procedures. So that the organizational service orientation is a particular pattern of the best, as far as possible, approach to giving superior value to customers.

Leadership is treated by many management theories as the first necessary condition for sustainable organization growth. Along with leadership, very often the strong and longreaching vision of an organization is mentioned as a critical success factor. Lytle et al. (1998) mention the particular importance of servant-leaders in the organizational service orientation. The direct engagement of servant-leaders in helping and assisting personnel leads to superior service; it builds special kind of unwritten standards informing staff how to perform a service. The service vision, which might be perceived as a kind of service manifesto, informs the whole staff on long-term objectives and goals.

The service encounter field refers to customer treatment and staff empowerment. How a service provider looks after customers is the first and the most important predicator of the quality perceived by them in many service industries. In the literature output there is a conformity of opinion that says that to get delighted customers it is required to allow direct contact staff to act with very unconstrained manners. Only in this case will employees be able to react flexibly to customers' needs and provide superior service.

All the service provided to customers exists in, and is produced by, a system. According to Deming, the most renowned quality management guru, in a system we should be looking for the potential for quality improvement as well as waste elimination (Deming, 1994). The service system has peculiar components that play a fundamental role in achieving service quality. One of them is failure prevention, and the second is service recovery. Traditionally failure analysis is distancing between internal and external failures; in service we have almost exclusively external failures - all the service production is carried out with the participation of clients. This clearly increases the importance of failure avoidance. On the other hand a failure might be an excellent chance to delight a customer, provided that a company has an effective, workable system to deal with complaints and faults. Service recovery might be a chance to win customer loyalty, including word-of-mouth (Swanson \& Kelley, 2001). According to Lytle et al. (1998) there are two more crucial factors from the point of view of achieving a high service quality system: technology utilisation and dissemination of service standards throughout an organization.

Most services are work intensive; the responsibility for the treatment of customers lies primarily in staff's hands. Individual personal skills, professional preparation, type of personality, mood and many other personal factors affect customers' experiences of quality. The employees' training and appropriate motivation process seem to be very beneficial in the field of human resource management practices.

Researchers have been asking themselves whether organizational service orientation is really crucial for customers' quality perception and business performance. According to some authors organizational service orientation plays a crucial role in the success of enterprises (Homburg et al., 2002; Walker, 2007). Service orientation is positively related to the main service delivery characteristics, and business performance as well. Empirical investigations show the important influence service orientation has on such variables as: service quality image, organizational commitment, and profitability (ROA) in the banking sector (Lytle \& Timmerman, 2006). Service orientation is also related to business 
performance characteristics, such as re-patronage intention and positive word-of-mouth, with the mediating role of staff satisfaction, service value, and customer, whose relationship was demonstrated in the medical service industry (Yoon et al., 2007).

It is conceivable that the issues contained in this concept have a substantial impact on organization-customer interactions, as well as the nature and quality of service delivery (Yoon et al., 2007). Organizational service orientation was also identified as a "common denominator" of educational service attributes that are responsible for clients' satisfaction (Walker, 2007). Nevertheless, in telecommunication call centres the organizational service orientation was identified as a factor that had no influence on service quality, whereas other service climate elements had a significant influence (Little \& Dean, 2006). On the other hand, service climate, which is a very similar concept, has been identified as negatively related to the owners' service values (the degree to which owners valued innovativeness, attentiveness, outcome-orientation, aggressiveness, support, and decisiveness) in the small business environment (Andrews \& Rogelberg, 2001).

According to Gonzalez \& Garazo (2006) the organizational service orientation has a positive influence on employees' satisfaction and organizational citizenship behaviour. Organizational citizenship behaviour was defined by researchers as three main variables: (1) whether employees act as representatives of the firm to outsiders, (2) contact-staff participation consists in providing information about customer needs and suggesting improvements in service delivery process, and (3) following company regulations in such a conscientious manner that they are adapted to the individual customer's needs (Gonzalez \& Garazo, 2006). In brief, organizational citizenship behaviour means "go the extra mile" for customers. These are very important elements of excellent service delivery.

The organizational service orientation as a diagnostic approach might also be used in the public services environment. Akesson et al. (2008) proposed areas of service orientation in public e-government services, and their theoretical analyses show that this concept provides a useful contribution to these particular services as well.

\section{Similarity to other concepts}

According to Vargo \& Lusch (2004, p. 11) interactivity, integration, customization and coproduction are the hallmarks of a service-centred approach. Along with these, focus on the customer and the relationship are also very important. In accordance with this thesis several approaches stresses the importance of the contact staff who directly provide the service, and their cultural context. Some authors mention that generally there are two important factors influencing employees' tendencies to provide the quality of service: the first one lies in the organization of a service company, and the second exists in individual personality characteristics (Baydoun et al., 2001; Homburg et al. 2002). The former is described by "macro-organizational approaches", like service climate and service orientation. The latter is the "personality-based approach" and it is focused on the personal skills and other features of staff, who are assessed by psychological tests and similar tools.

Organizational service orientation is often described in the context of service organization climate (Lytle \& Timmerman, 2006; Lynn et al., 2000; Lytle et al., 1998). Organizational climate and culture are interconnected. Employees' values and beliefs (part of culture) influence their interpretations of organizational policies, practices, and procedures (climate) 
(Schneider, 1996, p. 9). The organizational climate includes employees' perceptions of the policies, practices and procedures that are rewarded, supported, and expected concerning clients (Schneider et al., 2002). The climate of an organization is a summary of employees' impressions about "how we do things around here" or "what we focus on around here" or "what we direct our efforts to around here" (Schneider et al., 2006, p. 117). The climate is the psychological identity of employees in an organization. A climate is researched in the service environment context, and thus it is called service climate (Schneider, 1980; Schneider et al., 2006; Little \& Dean, 2006; Walker, 2007).

It can also be observed that the "customer service orientation" concept is in many ways similar to the organizational service orientation, but it is focused on staff behaviours and a more psychological interpretation. Customer service orientation is specified by interpersonal skills, extroversion, and the general disposition of operators having a positive influence on the operators' performance (Alge et al., 2002). It is still perceived as a part of the service climate. Walker (2007) classifies three service climate dimensions as "service orientation"; they are: staff service ethos, staff personal attributes, and staff concern for clients. They were found to be key elements of the organizational service climate. Little \& Dean (2006) also classify customer service orientation as a dimension of service climate. They propose four dimensions of service climate, and one of them is customer orientation, which is understood as the degree to which an organization tends to meet customer needs and expectations for service quality.

Baydoun et al. (2001) propose instruments for customer service orientation assessment. These demonstrate the utility of personality variables for predicting service behaviour. Based on this instrument high-quality service providers could be selected. There are more methods for customer service orientation assessment. Martin \& Fraser (2002) use the Customer Service Skills Inventory (CSSI) for identification of individuals who are likely to succeed in positions that involve working with the customers or clients of an organization. The CSSI is a short self-report measure of customer service orientation.

The literature also provides the "customer orientation" concept, derived from a relationship marketing approach. The customer orientation concerns service employees who have direct contact with customers. Hennig-Thurau \& Thurau (2003) propose customer orientation as a three-dimensional construct: employees' motivation to serve customers, their customeroriented skills, and self-perceived decision-making authority.

Finally, it is considered that organizational service orientation is part of a wider concept of an organization's overall climate. And it is necessary to admit that the organizational service orientation construct is not clearly defined (Lytle et al., 1998). But it seems to be very important from the point of view of a service firms' development: it mostly concerns an internal organizational system which is created by managers, and it provides a relatively precisely defined field for organizational changes and improvements which aim at service excellence; it might also be useful in organizing monitoring purposes, and in benchmarking others as well.

\section{How can organizational service orientation be measured?}

Organizational service orientation, as with other corporate culture related concepts, has been measured in many ways and in many service industries last two decades. Researchers 
have developed several diagnostic tools to identify the state of service orientation. For example, Andaleeb et al., 2007) used the specific survey tool to approximate doctors' service orientation, but in this case the concept of service orientation was understood as a set of doctors' behaviours towards their patients. The established construct of service orientation was more similar to the customer service orientation mentioned above.

A very useful tool for organizational service orientation measurement was proposed by Lytle et al. (1998), and it was named "Serv*Or". Serv*Or consists of 35 question items with Likert's scale. The questionnaire items describe four attributes of organizational service orientation, and these attributes altogether comprise 10 organizational service orientation dimensions. These attributes are contained in the four fields of practices briefly discussed above. These attributes (or dimensions) are as followed: servant leadership, service vision (service leadership practices), customer treatment, employee empowerment (service encounter practices), service failure prevention and recovery, service technology, service standards communication (service system practices), service training, and service rewards (human resource management practices) (Lytle et al., 1998).

The proposed diagnostic tool was tested and validated in the American banking sector and retail builders' suppliers. According to the authors, the Serv*Or tool demonstrates a crossindustry universal instrument for assessing service orientation in other firms, not just banks (Lytle et al., 1998). Authors mention that it can be used across different industries and also different work environments for service orientation diagnosis.

At a later time Serv ${ }^{*}$ Or tool was successfully used several times, inter alia, in the hospitality industry (Gonzalez \& Garazo, 2006), medical services (Yoon et al., 2007) and the banking sector (Lynn et al., 2000). Some authors also revised and proposed a modification to the Serv*Or scale. Lee et al. (2001) did this in the case of the hotel industry.

\section{Research aims and methods}

Despite research experience the organizational services orientation concept seems to be an interesting issue for further and deeper investigation. Nevertheless among evidence showing the positive role of organizational service orientation in service enterprises there are also exceptions. Moreover, we do not at this point have wide, cross-sector studies of this concept going through a large number of service sectors. The proposed research question is whether organizational service orientation is really a predicator of key business performance in the wide scope of service organizations operating in different service sectors. Is it still really important for customers' quality perceptions and for business performance? The organizational service orientation construct can be treated as a part of organizational culture, where specific national aspects play a significant role. One of the first studies on corporate culture stresses noticeable differences in organizations' culture among different countries (Hofstede, 1997). So it also seems interesting to investigate the state and role of organizational service orientation in the economic background of a post-communist country in Central Europe.

Furthermore, the next question is whether organization service orientation differs considerably across service sectors? It is obvious that services across different sectors have a different nature; depending on how close service staff is to customers, if the use of standardization is wide or not, what the roles of capital and human power are, etc. 
Investigation of organizational service orientation in a cross-industry context will create enhanced analytical opportunities. Therefore, it is worth identifying which aspects of organizational service orientation are different across the different types of service organizations. This can bring conclusions with reference to the role of service orientation dimensions across service sectors - which of them are equal in different service sectors and which are different in a definite way. Suggestions concerning the service orientation dimensions can be drawn up.

This study proposes the investigation of organizational service orientation in Poland, a Central-Eastern European economy. The empirical investigation was conducted in three regions of Poland: Podlasie, Mazowsze, and Warmia \& Mazury. Poland joined the EU in 2004; an adjustment programme lasting a few years had been established before that. After 1989, when the communist system collapsed, the Polish economy changed rapidly. The preparation for joining the EU was a strong improvement impulse for the Polish economy. Nowadays, this economy is in an upward phase (A Study..., 2011). According to the Central Statistical Office in Poland, in 2010 GDP growth amounted to 3.8\%, and mostly this was an effect of the increase in individual consumption. Poland was the best performing country in the OECD in 2009, with the economy recording economic growth of $1.7 \%$, and one of the few to avoid recession (Restoring Public Finances, 2011). In fact, Poland does not have huge services participation in comparison with other developed countries, but the service industry has great dynamics.

Serv*Or tool (Lytle et al., 1998) was employed, and a few significant service enterprises' business performance characteristics were also gathered. Organizational service orientation is treated as an independent variable, and service outcome as a dependent variables. In studying the problem of differences of organizational service orientation in service sectors the variable "service sector" is considered as the grouping one for ANOVA. In a deeper investigation of differences between sectors the Least Significant Difference method was employed.

A single enterprise was the research unit. The inquiries were addressed to a manager (or owner if he/she performed a managerial role) from an enterprise. Gonzalez \& Garazo (2006) also interviewed managers in the organizational service orientation identification process. The research population comprised 230 service enterprises operating in the three regions of Poland mentioned above, and the research units were chosen randomly. Trained field researchers visited managers in enterprises and asked them questions based on the questionnaire. The Serv* Or question battery was translated and modified, and some of the original research question were combined together so that all these could be clearly understood by respondents. At the same time the managerial language and notions typically used in Polish enterprises were employed. After the preoperational free interviews it was decided to employ the scale 1-5, which seemed to be better for respondents than seven gradual. For the service performance variables identification managerial subjective assessment was taken advantage of.

All the main sectors of the service industry were represented in the research sample (according to EU classification 24 sectors were detached specially for this study). Sectors were not represented equally. The largest ones that appeared in the sample were the construction and building renovation sector, and transport services (both 22 entities) and the 
smallest two: R\&D services (only one firm) and mineral resources exploitation services (also one). In the research sample there were mostly small and medium enterprises; those with fewer than 250 employees constituted $91.5 \%$ of the sample.

\section{The state of service orientation}

According to the above discussion, the organizational service orientation construct shows organization capability to provide excellent service to customers. Therefore, the gathered data will shed light on what extend the companies from the sample are able to offer excellent service to their customers. According to the data, the average score of organizational service orientation comes to 3.56 in the 5-point scale. The statistics are shown in Table 1.

\begin{tabular}{|l|c|c|c|}
\hline & Mean & Variance & SD \\
\hline Service orientation & $\mathbf{3 . 5 6}$ & $\mathbf{0 . 5 1 0}$ & $\mathbf{0 . 7 1 4}$ \\
\hline Service leadership practices & $\mathbf{4 . 0 2}$ & $\mathbf{0 . 9 2 2}$ & $\mathbf{0 . 9 6 0}$ \\
\hline Service vision & 4.12 & 1.042 & 1.021 \\
\hline Servant leadership & 4.00 & 1.299 & 1.140 \\
\hline Service encounter practices & $\mathbf{3 . 5 0}$ & $\mathbf{0 . 8 2 2}$ & $\mathbf{0 . 9 0 7}$ \\
\hline Customer treatment & 4.06 & 0.526 & 0.725 \\
\hline Employee empowerment & 2.99 & 1.680 & 1.296 \\
\hline Service systems practices & $\mathbf{3 . 4 6}$ & $\mathbf{0 . 6 8 3}$ & $\mathbf{0 . 8 2 6}$ \\
\hline Service technology & 3.61 & 1.221 & 1.105 \\
\hline Service failure prevention & 3.71 & 1.063 & 1.031 \\
\hline Service failure recovery & 3.41 & 1.080 & 1.039 \\
\hline Service standards communication & 3.39 & 0.927 & 0.963 \\
\hline Human resource management practices & $\mathbf{3 . 2 2}$ & $\mathbf{1 . 1 2 8}$ & $\mathbf{1 . 0 6 2}$ \\
\hline Service rewards & 3.11 & 1.248 & 1.117 \\
\hline Service training & 3.39 & 1.538 & 1.240 \\
\hline
\end{tabular}

Table 1. Serv* Or variables scores

Going deeply into the attributes of the organizational service orientation it is noticeable that "service leadership practices" are the most highly scored field of this concept in researched enterprises. Scores above four points might be judged as very good. This field contains the strong vision of a service and the stressed role of customers among managers and service staff, as well as managers' personal involvement in service providing process. Leadership is considered by many theories as the primary success factor, and as the basis for building an effective business organization. For example the ISO 9001 standard of quality system also sees leadership as the first basic condition for quality improvement (paragraph 5 of ISO 9001:2008, Requirements for Management).

A very interesting situation is recognised in the field "service encounter practice". On one hand, it is one of the most highly scored variables - "customer treatment", and on the other 
hand, the attribute "employee empowerment" which is the least scored (and with the largest projection of results; see the variation and the standard deviation). It seems that in the researched enterprises there is a strong focus on providing very good treatment to the customers, but this is done according to standards which are strictly defined in advance. Staff have very little space for free and flexible initiatives. It also suggests that managers prefer having wide control of all operations while serving customers. Nevertheless, leaving so little space, they seriously limit the potential for moments of truth creation. According to Carlson (1987), moments of truth are the essence of superior quality experiences in service.

The system is next to leadership as the primary force standing behind the sustainable growth of any organization, especially in the context of quality improvement. The "service system practices" are performed at a moderate level. It is noticeable that failure prevention practices are particularly important. Considering the organizational service orientation fields level "human resource management practices" seems to be the weakness of the researched companies.

The observations which emerged from the study might be partly explained by the managerial attitudes specific for the country where the research was conducted. Managers in Poland, a country with a heritage of central planning, still prefer to focus on the individual. They consider management success as a single person's achievement, rather than a team success. Hence the importance of strong leadership and very little space for staff empowerment.

\section{The link between organizational service orientation and business performance}

During interviews with managers the basic data concerning companies' business performance were gathered. First of all, the overall service quality level was identified, as well as changes in enterprises' market share, changes in profitability, client satisfaction and client loyalty. The correlation coefficients were counted between all organizational service orientation fields, and also the global score of the construct with all the above-mentioned performance variables. The results of correlations' calculation are presented in Table 2, with the non-significant $(\mathrm{p}>0.05)$ relationships removed.

There are significant relationships between most organizational service orientation fields and business performance variables. However, the values of correlation coefficients are not high. The number of identified significant relationships allows the conclusion that there is an influence of organizational service orientation on many business performance variables. The values of correlation coefficients would not be expected to be as high because of the great diversity of services in the research sample. Correlation analysis proves that organizational service orientation is a very important predicator of service quality performance. So, it could be considered that the organizational service orientation construct is a fairly good measure which can assess the ability of a service organization to provide excellent service. Taking into consideration that many service sectors were examined, it also allows the suggestion that Serv*Or could be a universal cross-sector tool.

A fairly strong influence was observed on overall service quality. Human resource management practices especially emerge as the most influential. This variable has the highest 
coefficient value. It underlines the role of the effective motivation of staff, as well as the importance of knowledge and training. The next performance variable, which in a significant way is affected by organizational service orientation is client loyalty. The correlation coefficients are significant with all fields, the same as in the case of human resource management practices. The importance of organizational service orientation as a loyalty predicator reinforces the role of direct contact service personnel in clients' loyalty building.

\begin{tabular}{|c|c|c|c|}
\hline & & Gamma & p level \\
\hline Service orientation & \multirow{5}{*}{ \& Quality level } & 0.331 & 0.000 \\
\hline Service leadership practices & & 0.216 & 0.001 \\
\hline Service encounter practices & & 0.263 & 0.000 \\
\hline Service systems practices & & 0.245 & 0.000 \\
\hline Human resource management practices & & 0.308 & 0.000 \\
\hline Service orientation & \multirow{3}{*}{ \& Market share } & 0.169 & 0.003 \\
\hline Service systems practices & & 0.142 & 0.012 \\
\hline Human resource management practices & & 0.189 & 0.001 \\
\hline Service orientation & \multirow{4}{*}{ \& Profitability } & 0.220 & 0.000 \\
\hline Service leadership practices & & 0.163 & 0.006 \\
\hline Service systems practices & & 0.141 & 0.011 \\
\hline Human resource management practices & & 0.231 & 0.000 \\
\hline Service orientation & \multirow{4}{*}{$\begin{array}{c}\text { \& Client } \\
\text { satisfaction }\end{array}$} & 0.243 & 0.000 \\
\hline Service leadership practices & & 0.271 & 0.000 \\
\hline Service systems practices & & 0.173 & 0.002 \\
\hline Human resource management practices & & 0.203 & 0.000 \\
\hline Service orientation & \multirow{5}{*}{ \& Client loyalty } & 0.256 & 0.000 \\
\hline Service leadership practices & & 0.237 & 0.000 \\
\hline Service encounter practices & & 0.151 & 0.006 \\
\hline Service systems practices & & 0.178 & 0.001 \\
\hline Human resource management practices & & 0.196 & 0.000 \\
\hline
\end{tabular}

Table 2. Correlations between organizational service orientation and business performance

We should also pay attention to the fact that there is a field (service encounter practices) which is correlated with loyalty and not correlated with client satisfaction. Satisfaction might be the main loyalty predicator but not often (Oliver, 1999). Nevertheless, loyalty 
seems to be one of the most important business performance components (Reichheld \& Teal, 2001) and the role of service orientation in wining loyal clients seems to be very beneficial.

\section{The differences between service sectors}

There were 25 categories in the variable "service sector", and one of them was "others". It was decided to employ ANOVA to investigate if there are significant differences in organizational service orientation scores between service sectors. Sectors were not represented equally, and some of them included small entities, and therefore the service sectors including fewer than five entities were rejected from the sample. A one-way ANOVA provides results, as shown in Table 3.

Taking into consideration the variances in different service sectors, there is not a significant difference in the global organizational service orientation score. Also, many of attributes do not show significant differences. But some particular organizational service orientation dimensions vary significantly between sectors. The largest diversity is noticed within "service encounter practices". It seems that service encounter is the most important aspect that diversifies service orientation across sectors. It might be expected that the most remote contact with clients does not require superior organizational service orientation, and that closer and direct relationships require a special kind of service encounter practices. This also concerns services provided to business clients, as this particular kind of relationship requires a different approach in direct contacts. Unfortunately, service sectors were separated using as a basis the Statistical Classification of Economic Activities in the European Community (NACE), which does not allow a clear distinction between B2B and B2C services.

The ANOVA analysis encourages deeper and more detailed explorations related to the service orientation differentials across service sectors. For these purposes Fisher's LSD (Least Significant Difference) procedure should be applied. It allows the investigation of the individual differences between particular variables in pairs of sectors. But in this case it is complicated to trace it in detail because of the great number of pairs (there are hundreds of pairs of sectors and service orientation attributes).

With the support of Statistica software the LSD significances were counted for five organizational service orientation dimensions: those for which simple analysis of variance showed significant differences: service vision, customer treatment, employee empowerment, service standards communication, and service training. For each service sector the numbers of significant pairs were summed up together. In the five organizational service orientation dimensions mentioned above the greatest number of significant pairs of service sectors were identified in "telecommunications and postal services" - altogether 29 pairs, the next one was "construction and renovation services" - altogether 26 pairs, next "vehicle services and petrol retailing" - 19 pairs. Counting the pairs for service orientation variables, most of them were found in "customer treatment" - 55, and "service standards communication" - 46. The LSD output was evaluated and interpreted with great care, having all the time in mind the fact that service sectors are not represented equally in the research sample. The numbers of significant pairs are presented in Table 4 (the classification "others" is excluded, as well as the small numerous sectors). 


\begin{tabular}{|l|l|l|l|l|l|l|l|l|}
\hline & SS & df & MS & SS & df & MS & F & p \\
\hline Service orientation & 10.393 & 18 & 0.577 & 78.289 & 198 & 0.395 & 1.460 & NS \\
\hline Service leadership practices & 15.006 & 18 & 0.834 & 186.379 & 199 & 0.937 & 0.890 & NS \\
\hline Service vision & 36.895 & 18 & 2.050 & 186.958 & 198 & 0.944 & 2.171 & 0.005 \\
\hline Servant leadership & 21.518 & 18 & 1.195 & 258.482 & 195 & 1.326 & 0.902 & NS \\
\hline Service encounter practices & 26.498 & 18 & 1.472 & 151.823 & 199 & 0.763 & 1.930 & 0.015 \\
\hline Customer treatment & 22.922 & 18 & 1.273 & 90.756 & 197 & 0.461 & 2.764 & 0.000 \\
\hline Employee empowerment & 61.169 & 18 & 3.398 & 295.826 & 196 & 1.509 & 2.252 & 0.004 \\
\hline Service systems practices & 8.731 & 18 & 0.485 & 142.915 & 199 & 0.718 & 0.675 & NS \\
\hline Service technology & 12.364 & 18 & 0.687 & 244.901 & 189 & 1.296 & 0.530 & NS \\
\hline Service failure prevention & 15.440 & 18 & 0.858 & 206.008 & 193 & 1.067 & 0.804 & NS \\
\hline Service failure recovery & 15.883 & 18 & 0.882 & 216.706 & 196 & 1.106 & 0.798 & NS \\
\hline Service standards communication & 27.559 & 18 & 1.531 & 171.805 & 197 & 0.872 & 1.756 & 0.033 \\
\hline $\begin{array}{l}\text { Human resource management } \\
\text { practices }\end{array}$ & 25.307 & 18 & 1.406 & 215.557 & 199 & 1.083 & 1.298 & NS \\
\hline Service rewards & 29.105 & 18 & 1.617 & 230.411 & 194 & 1.188 & 1.361 & NS \\
\hline Service training & 55.293 & 18 & 3.072 & 271.697 & 197 & 1.379 & 2.227 & 0.004 \\
\hline NS - non-significant (p>0.05) & & & & & & \\
\hline
\end{tabular}

Table 3. ANOVA analysis results

First of all we should focus our attention on the telecommunications and postal services, which are, in fact, very specific. There are still state monopolies in a few kinds of service, namely letter delivery; and in phone call services there are only a few strong market players, as in most European countries. It is not a mystery that in most European countries these services very often cause customers to complain; we have also observed action taken by the European Commission prepared to exert change in this market. In the researched country, the telecommunications and postal services sector structure remains largely unchanged from previous years, which influences particular practices in treating customers. In this sector there is rather remote contact between service staff and customers, which surely drives specific organizational service orientation in the variable of "customer treatment", and some others.

The second very interesting sector, which appears to be noticeably different from, this is construction and renovation services. This sector provides services with rather low personal contact with customers. Most of the researched firms provide services as subcontractors on huge building sites, having no, or almost no, contact with the investor, even if he/she is an individual. Taking care of customer and service quality in this sector does not rely on personal interaction to a great extent, but instead it lies in solid manual work and technical 
support. Perfection in this case is not kindness and the customer's understanding, but in fact it is in doing a professional, timely and robust job. Vehicle repairing and the petrol retailing sector is also characterised by the strong role of service equipment and manual cleverness. Analysing the sectors which differ the most, it might be concluded that service features probably affect the state of organizational service orientation very much, and this explains the differentiation which was identified in the research sample.

\begin{tabular}{|c|c|c|c|c|c|c|}
\hline & $\begin{array}{l}\text { Customer } \\
\text { treatment }\end{array}$ & $\begin{array}{l}\text { Employee } \\
\text { emp. }\end{array}$ & $\begin{array}{l}\text { Standards } \\
\text { comm. }\end{array}$ & $\begin{array}{l}\text { Service } \\
\text { vision }\end{array}$ & $\begin{array}{l}\text { Service } \\
\text { training }\end{array}$ & $\begin{array}{l}\text { Row } \\
\text { sums }\end{array}$ \\
\hline $\begin{array}{l}\text { Telecommunications and } \\
\text { postal services }\end{array}$ & 16 & 3 & 6 & 1 & 3 & 29 \\
\hline $\begin{array}{l}\text { Construction and renovation } \\
\text { services }\end{array}$ & 3 & 3 & 7 & 8 & 5 & 26 \\
\hline $\begin{array}{l}\text { Vehicle services and petrol } \\
\text { retailing }\end{array}$ & 3 & - & 6 & 6 & 4 & 19 \\
\hline Retailing & 2 & 2 & 4 & 8 & 1 & 17 \\
\hline $\begin{array}{l}\text { Hotel and restaurant } \\
\text { industry }\end{array}$ & 2 & 2 & 5 & 2 & 6 & 17 \\
\hline $\begin{array}{l}\text { Finance and insurance } \\
\text { services }\end{array}$ & 7 & 3 & 6 & 1 & - & 17 \\
\hline $\begin{array}{l}\text { Agriculture and wood } \\
\text { services }\end{array}$ & 1 & 3 & 4 & 2 & - & 10 \\
\hline $\begin{array}{l}\text { Health and social care } \\
\text { services }\end{array}$ & 4 & 6 & - & - & - & 10 \\
\hline Business services & 3 & - & 1 & 2 & 2 & 8 \\
\hline $\begin{array}{l}\text { Wholesale and commission } \\
\text { trading }\end{array}$ & 2 & - & 4 & 1 & - & 7 \\
\hline Transport services & 3 & - & 1 & 2 & 1 & 7 \\
\hline Printing services & 2 & - & - & 1 & 3 & 6 \\
\hline IT services & 1 & 4 & - & 1 & & 6 \\
\hline $\begin{array}{l}\text { Waste util., energy and water } \\
\text { supply }\end{array}$ & 2 & - & - & 1 & 2 & 5 \\
\hline $\begin{array}{l}\text { Services connected with } \\
\text { fabrics }\end{array}$ & 1 & - & - & 2 & 1 & 4 \\
\hline Education & 2 & - & 2 & - & - & 4 \\
\hline Culture and sport services & 1 & - & - & - & - & 1 \\
\hline Sum in columns & 55 & 26 & 46 & 38 & 28 & \\
\hline
\end{tabular}

Table 4. Numbers of significant pairs

LSD analysis has brought one more additional advantage. Thanks to the number of pairs, we were able to recognize "service standards communication" as a variable which is 
differentiated very much across service sectors (46 significant pairs). Different sectors have their own approaches to communicating service standards, as well as the manners by which they define them. For example in construction work we have a completely different approach to standards spreading than in financial services. The former is based on the individual's knowledge and skills, as well as on the technical control, while the latter is based on the kindness of individual staff, and intensively uses IT technology to define and to execute standards.

\section{Conclusions and managerial implications}

This study strongly suggests that organizational service orientation plays an important role in achieving business performance by service organizations. Its influence on service quality and client loyalty is substantial, and it also leads to better finance results. Considering that the researched concept is a credible predicator of the quality of service output, it should be used more often in service organizations diagnosis. It might serve managers and consultants as an assessment approach for organizational ability to provide excellent service to clients. Moreover, it might provide a great framework for service organization improvement, acting as a guide for setting up improvement programmes.

The organizational service orientation concept is closely related to the corporate culture concept, but at the same time it is focused only on behaviours (practices) within organizations. And the research has pointed out that it is a powerful approach for investigating how a service organization deals with a service encounter. The concept definitely helps more in the field of practical service organization than in corporate culture recognition. It may be, of course, on one hand as an advantage, but on the other as a weakness.

The concepts of organizational culture or climate might discourage managers because there are so many intangible elements that are difficult for direct observation. But using the Serv*Or instrument, as proposed in this study, it might be beneficial that it does not measure values and beliefs, but it is only focused on practices within the organization. Thanks to this, it is more universal, and it has a potential for use in many cultures and a variety of nations.

The state of organizational service orientation in the researched sample of service providers shows that the weakest element is employee empowerment, which surely originates partly from the national inclination to individualism, and partly from the central planning system that existed in the Polish economy in communist times. On the other hand, there is a very good score in leadership. These observations look coherent because expanded individualism usually fosters strong leadership. The high score in customer treatment proves that among the researched companies strong market orientation is adapted effectively. But these companies do not take full advantage of the possibility of moments-of-truth creation. According to Carlzon (1987) and Gronroos (2007) moments of truth, of course we mean moments of magic, are one of the crucial elements in gaining a superior perceptions of service quality.

The study adopts a cross-sector approach, and thus the diversity between service sectors might be investigated. Wide cross-sector studies are rather a seldom practice in the quality management field, and in this study it was a challenging problem. It was not proved that 
general indicators of organizational service orientation varied between service sectors, which on the other hands supports the assumption of the universality and wide applicability of the researched concept. However, the calculations allow us to point out some organizational service orientation dimensions that differ noticeably across sectors, i.e. service encounter practices and service standards communication.

There are two important factors that in an appreciable way affect organizational service orientation differentiation between service sectors: the first one, let us call it the "structural factor", relies on the fact that a service orientation is affected by the structure of a sector, like the diversity of companies and competition level; the second one comes from the service providing process characteristics, especially the intensiveness of close and direct relationships between service staff and customers.

All studies have some limitations, and this one has as well. The most important limitation of this study may be found in the fact that the respondents in the researched enterprises were only managers. Their points of view might be different from those of all the staff who are employed in the enterprises. The representation of respondents in particular sectors was also too small, and unfortunately not equal.

\section{References}

A Study of Poland's Economic Performance in The 1st Quarter of 2011 (2011). Ministry of Economy in Polnad, Warsaw, May 2011.

Akesson, M. ; Skalen, P. \&Edvardsson, B. (2008). E-government and service orientation: gaps between theory and practice. International Journal of Public Sector Management, Vol.21, No.1, pp. 74-92, ISSN 0951-3558

Alge, B.J. ; Gresham, M.T. ; Heneman, R.L. ; Fox, J. \& McMasters, R. (2002). Measuring customer service orientation using a measure of interpersonal skills: a preliminary test in a public service organization. Journal of Business and Psychology, Vol.16, No.3, pp. 467-476, ISSN 0889-3268

Andaleeb, S.S. ; Siddiqui, N. \& Khandakar, S. (2007). Doctors' service orientation in public, private, and foreign hospitals. International Journal of Health Care Quality Assurance, Vol.20, No.3, pp. 253-263, ISSN 0952-6862

Andrews, T.L. \& Rogelberg, S.G. (2001). A new look at service climate: its relationship with owner service values in small businesses. Journal of Business and Psychology, Vol.16, No.1, pp. 119-131, ISSN 0889-3268

Baydoun, R.; Rose D. \& Emperado, T. (2001). Measuring customer service orientation: an examination of the validity of the customer service profile. Journal of Business and Psychology, Vol.15, No.4, pp. 605-602, ISSN 0889-3268

Beitelspacher, L.S. ; Richey, R.G. \& Reynolds, K.E. (2011) Exploring a new perspective on service efficiency: service culture in retail organizations. Journal of Services Marketing, Vol.25, No.3, pp. 215-228, ISSN 0887-6045

Carlzon, J. (1987). Moments of Truth, Ballinger Pub., ISBN 0-06-091580-3, Cambridge, USA

Deming, E. (1994). The New Economincs, The MIT Press, ISBN 0-262-54116-5, Cambridge, USA

Furrer, O.; Liu, B. \& Sudharshan, D. (2000). The relationships between culture and service quality perceptions: basis for cross-cultural market segmentation and resource allocation. Journal of Service Research, Vol.2, No.4, pp. 355-71, ISSN 1094-6705 
Gebauer, H.; Edvardsson, B. \& Bjurko, M. (2010). The impact of service orientation in corporate culture on business performance in manufacturing companies. Journal of Service Management, Vol.21, No.2, pp. 237-259, ISSN 1757-5818

Gonzalez, J.V. \& Garazo, T.G. (2006). Structural relationships between organizational service orientation, contact employee job satisfaction and citizenship behaviour. International Journal of Service Industry Management, Vol.17, No.1, pp. 23-50, ISSN 0956-4233

Gronroos, Ch. (2007). Service Marketing and Management. Customer Management in Service Competition, John Wiley \& Sons, ISBN 978-0-470-02862-9, Hoboken, USA

Hennig-Thurau, T. \& Thurau, C. (2003). Customer Orientation of Service Employees Toward a Conceptual Framework of a Key Relationship Marketing Construct. Journal of Relationship Marketing, Vol.2(1/2), pp. 23-41, ISSN 1533-2667

Heskett, J.L.; Jones, T.O.; Loveman, G.W.; Earl Sasser, Jr.W. \& Schlesinger, L.A. (2008). Putting the service-profit chain to work. Harvard Business Review, July-August, pp. 118-129, ISSN 0017-8012

Hofstede, G. (1997). Cultures and Organizations. Software of the Minds, McGrow-Hill, ISBN 978-0-9742114-7-3, New York, USA

Homburg, C. ; Hoyer, W.D. \& Fassnacht, M. (2002). Service Orientation of a Retailer's Business Strategy: Dimensions, Antecedents, and Performance Outcomes. Journal of Marketing, Vol.66, pp. 86-101, ISSN 0022-2429

Hsieh, Y.M. \& Hsieh, A.T. (2001). Enhancement of service quality with job standardisation. The Service Industries Journal, Vol.21, No.3, pp. 147-166, ISSN 0264-2069

Johnston, R., \& Clark, G. (2005). Service operations management, (2nd Ed.), Prentice-Hall, ISBN 978-0070037939, Harlow, England

Kanousi, A. (2005). An empirical investigation of the role of culture on service recovery expectations. Managing Service Quality, Vol.15, No.1, pp. 57-69, ISSN 0960-4529

Kantsperger, R., \& Kunz, W.H. (2005). Managing overall service quality in customer care centers. Empirical findings of a multi-perspective approach. International Journal of Service Industry Management, Vol.16, No.2, pp. 135-151, ISSN 0956-4233

Lee, Y.K. ; Park, D.H. \& Yoo, D.K. (2001). The structural relationship between service orientation, mediators and business performance in Korean hotel firms. Tourism Sciences, Vol.21, No.1, pp. 49-65, ISSN 1006-575X

Little, M.M. \& Dean, A.M. (2006). Links between service climate, employee commitment and employees' service quality capability. Managing Service Quality, Vol.16, No.5, pp. 460-476, ISSN 0960-4529

Lynn, M.L. ; Lytle, R.S. \& Bobek, S. (2000). Service orientation in transitional markets: does it matter? European Journal of Marketing, Vol.34, No.3/4, pp. 279-298, ISSN 0309-0566

Lytle, R.S. \& Timmerman, J.E. (2006). Service orientation and performance: an organizational perspective. Journal of Services Marketing, Vol.20/2, pp. 136-147, ISSN 0887-6045

Lytle, R.S.; Hom, P.W. \& Mokwa, M.P. (1998). Serv*Or: A Managerial Measure of Organizational Service-Orientation. Journal of Retailing, Vol.74, Issue4, pp. 455-489. ISSN 0022-4359

Martin, L.A. \& Fraser, S.L. (2002). Customer service orientation in managerial and nonmanagerial employees: an exploratory study. Journal of Business and Psychology, Vol.16, No.3, pp. 477-484, ISSN 0889-3268 
Mukherjee, A. \& Malhotra, N. (2006). Does role clarity explain employee-perceived service quality? A study of antecedents and consequences in call centres. International Journal of Service Industry Management, Vol.17, No.5, pp. 444-473, ISSN 0956-4233

Oliver, R.L. (1999). Whence Consumer Loyalty? Journal of Marketing, Vol.63, Issue 4 (Special Issue), pp. 33-44, ISSN 0022-2429

Parasuraman, A.; Zeithaml, V.A. \& Berry, L.L. (1988). SERVQUAL: A multiple-item scale for measuring consumer perceptions of service quality. Journal of Retailing, Vol.64, Issue1, pp. 12-40, ISSN 0022-4359

Peters, T. \& Waterman, R.H. (1982). In Search of Excellence. Lessons from America's Best-Run Companies, A Warner Communications Company, ISBN 0-446-38281-7, New York, USA

Reichheld, F.F. \& Teal, T. (2001). Loyalty Effect: The Hidden Force Behind Growth, Profits, and Lasting Value, Harvard Business School Press Books, ISBN 978-1578516872, Boston, USA

Restoring Public Finances (2011). Special Issue of the OECD Journal on Budgeting, Vol.2011/2, pp. 1-216, ISSN 1608-7143

Schneider, B. (1980). The Service Organization: Climate Is Crucial. Organizational Dynamics, Vol.9, Issue2, pp. 52-65, ISSN 0090-2616

Schneider, B. (1988). Notes on climate and culture, In: Lovelock, C., (Ed.), Managing Services, Prentice-Hall, ISBN 0-13-544701-1, Englewood Cliffs, USA

Schneider, B.; Brief, A.P. \& Guzzo, R.A. (1996). Creating a Climate and Culture for Sustainable Organizational Change. Organizational Dynamics, Vol.24, Issue4, pp. 719, ISSN 0090-2616

Schneider, B. ; Salvaggio, A. \& Subirats, M. (2002). Climate strength: a new direction for climate research. Journal of Applied Psychology, Vol.87, pp. 220-229, ISSN 0021-9010

Schneider, B.; Macey, W.H. \& Young, S.A. (2006). The Climate for Service: A Review of the Construct with Implications for Achieving CLV Goals. Journal of Relationship Marketing, Vol.5, Issue2/3, pp. 111-132, ISSN 1533-2667

Schneider, B.; White, S.S. \& Paul, M.C. (1998). Linking service climate and customer perceptions of service quality: Test of a casual model. Journal of Applied Psychology, Vol. 83, Issue2, pp. 150-163, ISSN 0021-9010

Specht, N.; Fichtel, S., \& Meyer, A. (2007). Perception and attribution of employees' effort and abilities. The impact on customer encounter satisfaction. International Journal of Service Industry Management, Vol.18, No.5, pp. 534-554, ISSN 0956-4233

Swanson, S.R. \& Kelley, S.W. (2001). Service recovery attributions and word-of-mouth intentions. European Journal of Marketing, Vol.35, No.1/2, pp. 194-211, ISSN 03090566

Ueno, A. (2008). Is empowerment really a contributory factor to service quality? The Service Industries Journal, Vol.28, No.9, pp. 1321-1335, ISSN 0264-2069

Urban, W. (2011). Perceived quality versus quality of processes; a meta concept of service quality measurement. The Service Industries Journal, DOI:10.1080/02642069.2011.614337, ISSN 0264-2069

Vargo, S.L. \& Lusch, R.F. (2004). Evolving to a New Dominant Logic for Marketing. Journal of Marketing, Vol.68 (January), pp. 1-17, ISSN 0022-2429

Walker, J. (2007). Service climate in New Zealand English language centres. Journal of Educational Administration, Vol.45, No.3, pp. 315-337, ISSN 0957-8234 
Winsted, K.F. (1997). The service experience in two cultures: a behavioral perspective. Journal of Retailing, Vol.73, No.3, pp. 337-60, ISSN 0022-4359

Yoon, S.J. ; Choi, D.C. \& Park, J.W. (2007). Service Orientation: Its Impact on Business Performance in the Medical Service Industry. The Service Industries Journal, Vol.27, No.4, pp. 371-388, ISSN 0264-2069 


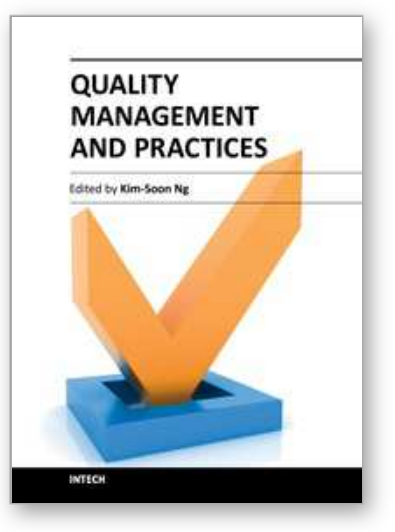

\author{
Quality Management and Practices \\ Edited by Dr. Kim-Soon Ng
}

ISBN 978-953-51-0550-3

Hard cover, 254 pages

Publisher InTech

Published online 27, April, 2012

Published in print edition April, 2012

This book is comprised of a collection of reviews and research works from international professionals from various parts of the world. A practical approach to quality management provides the reader with the understanding of basic to total quality practices in organizations, reflecting a systematic coverage of topics. Its main focus is on quality management practices in organization and dealing with specific total quality practices to quality management systems. It is intended for use as a reference at the universities, colleges, corporate organizations, and for individuals who want to know more about total quality practices. The works in this book will be a helpful and useful guide to practitioners seeking to understand and use the appropriate approaches to implement total quality.

\title{
How to reference
}

In order to correctly reference this scholarly work, feel free to copy and paste the following:

Wieslaw Urban (2012). Organizational Service Orientation as a Quality Predicator in Services, Quality Management and Practices, Dr. Kim-Soon Ng (Ed.), ISBN: 978-953-51-0550-3, InTech, Available from: http://www.intechopen.com/books/quality-management-and-practices/organizational-service-orientation-as-aquality-predicator-in-services

\section{INTECH}

open science | open minds

\section{InTech Europe}

University Campus STeP Ri

Slavka Krautzeka 83/A

51000 Rijeka, Croatia

Phone: +385 (51) 770447

Fax: +385 (51) 686166

www.intechopen.com

\section{InTech China}

Unit 405, Office Block, Hotel Equatorial Shanghai

No.65, Yan An Road (West), Shanghai, 200040, China

中国上海市延安西路65号上海国际贵都大饭店办公楼 405 单元

Phone: +86-21-62489820

Fax: +86-21-62489821 
(C) 2012 The Author(s). Licensee IntechOpen. This is an open access article distributed under the terms of the Creative Commons Attribution 3.0 License, which permits unrestricted use, distribution, and reproduction in any medium, provided the original work is properly cited. 